\title{
EMS 14001: An Instrument for Environmental Protection- A Petrochemical Perspective
}

\author{
Zeittey Karmilla Bte Kaman ${ }^{1}$ and Zaleha Othman ${ }^{2}$ \\ ${ }^{1}$ Institute of Energy Policy and Research (IEPRe) Universiti Tenaga Nasional. \\ ${ }^{2}$ Othman Yeop Abdullah Graduate School of Business Universiti Utara Malaysia
}

\begin{abstract}
The purpose of this paper is to explain the process of environmental protection in one of the leading petrochemical company in Malaysia. In so doing, the paper shared its findings by using a single case study. The paper indicates that EMS ISO14001 is an environmental protection mechanism that guide company, particularly of same nature i.e. petrochemical. The paper shows that environment problems caused by petrochemical companies has both practical and environmental implications. The effects of environmental degradations on the habitat and society are serious, thus the findings add value to minimize if not reduce environmental issue. The paper contributes to new knowledge in several ways; emphasized on the use of EMS ISO 14001 as means of environmental protection model and giving original idea that broaden the perspective of environmental protection.
\end{abstract}

Key words: environmental protection, EMS ISO 14001, case study

\section{INTRODUCTION}

Environmental hazards is an issue that is constantly debated, both by academia and practitioners. The rapid increase of the environmental hazards escalates the attention given to protect the environment even more [1][2][3]. There are views that the environmental hazards are often linked with petrochemical industries. Only recently, there was an incident of major oil spilt been reported in the news, where up to six tonnes of diesel and hundreds of litres of engine oil floated from Penang seas towards Perak, both in Malaysia. This threated not only the ocean habitat, rather the coastal environment. It was reported that a vessel's fuel and engine oil hit the remains of a shipwreck [4]. There are many such cases that give rise to the need of an environmental protection mechanism. With proper implementation of the environmental protection, such as EMS 14001, the petrochemical industry could minimize if not eliminate the environmental hazards issue in future. Therefore, it is essential to study the process of how EMS 14001 mitigate environmental hazard in order to protect the environment. Thus, the purpose of this study is find the theoretical link between EMS 14001 to environmental protection. The paper identifies key components from the EMS 14001 that are relevant towards environmental protection. The study adopted a single case study to identify the type of information that are recognized as the components relevant to support environmental protection, in petrochemical industry. The study contributes to extant environmental protection literature. The remaining section of this paper are organized as follows. Following section deliberate on the literature review. Subsequent section states the methodology employed to examine the study. Next, results and findings of the study are shared. Finally, concluding remarks and future research are elaborated.

\section{PROBLEM STATEMENT}

In recent years, the occurrence of environmental hazards escalates worldwide. There are views that industries play a role in contributing to the alarming rate of the environmental hazards. In Malaysia, many cases of environmental hazards relate with petrochemical. For example, in September 2013, 4,000 litres of used engine oil was dumped into a Selangor river by the factories nearby and caused water supply disruptions to one million customers in the Klang Valley. Recently, in 24 July 2018 authorities ordered three plastic factories in Kuala Langat to close due to pollution [5]. The increase number of environmental disasters around the world has stressed the importance of environmental protection among companies both internationally and in Malaysia. 
Many believes that the existing laws on environmental protection is insufficient and corporations should take responsibilities to provide measures to safeguard the environment. Government around the world, including Malaysia are seeking effective measures to address the issue in regards to protecting the environment. Some opine that ISO 14001, which is a voluntary standard that established criteria for environmental management system (EMS) is a solution that support the lack of laws in regards to the environmental protection. EMS is a systematic process established to manage environmental impact and reside environment risk [6][7] as cited in [8]. According to Zhang, Wang and Wang [8] "adoption of EMS (ISO14001) has constituted one of the most important elements of corporate sustainability around the world within different industries, including chemical" (p.1)

Although the implementation of EMS 14001 has a long way to go, it is emerging as an instrument towards protecting the environmental, particularly to environmental sensitive industries such as petrochemical industry. Zhang, Wang and Wang (2014) [8] claimed that EMS 14001 is an important instrument for corporations that are of environmental sensitive industries. Although EMS 14001 have been established for many years, it is rarely been examined in the literature [8].

\section{LITERATURE REVIEW}

The main stream of literature focused examining the drivers for green purchase adoption among EMS 14001 certified companies in Malaysia ElTayeb et al., [9] perceived benefits derived from ISO14001 registrations for firms in a newly industrialized country like Malaysia [10]; linking the adoption of an EMS ISO14001 with valuebased thinking and sustainability [11] describing the underlying structure of the ISO 14001 motives, difficulties and benefits and determining the respective latent constructs [12]; investigating how a group of companies have developed a pattern to design a sustainability supply chain based on several requirements, including ISO 14001 [13]; providing an immediate image about the reality of the EMS as experienced by Algerian certified ISO 14001 companies [14]; and the effect of ISO 14001 on environmental regulatory compliance in China [15].

By investigating current CSR practices (i.e. EMS ISO14001 internal process) in Company A towards environmental protection, the case study method has allowed the researcher to add to the existing literature and offered a model of CSR practices in a chemical company. Even though previous research has indicated the importance of EMS ISO14001 towards environmental protection (EP), very few focused on "how" EMS ISO14001 internal process leads to EP. Such study is very important so that the academics and practitioners benefit from the indepth process employed at one leading petrochemical company in Malaysia.

Therefore, the aim of the paper is to explain the process of EMS 14001 adopted by a petrochemical company in Malaysia as instrument towards environmental protection. The paper emphasised on the standards in the contexts of its potential to advance companies adoption of environmental protection. Given the importance of the issue, the lack of environmental protection tool and the limitation of the rules and regulations in respect of environmental protection, the paper contributes to the knowledge of how company use EMS 14001 as environmental protection tool. The findings are useful for companies of such industry to adopt systematic standards that could guide them through achieving sustainable future.

\section{RESEARCH QUESTION}

Through the literature review, the following research question is developed:

QI: How EMS 14001 responding to environmental protection initiative in Company? In this case, Company A.

\section{RESEARCH METHOD: A SINGLE CASE STUDY}

Qualitative research methodology was used to examine the process of EMS 14001 as instrument for environmental protection. Qualitative methodology is most commonly applied when phenomena are insufficiently understood [16]. Considering the topic is understudy, qualitative methodology is thus suited. According to Corbin and Strauss [17], qualitative research allows researchers to get at the inner experience of a participant, to determine how meanings are formed through and in a culture, and to discover rather than test variables. To be specific, a case study method was adopted to examine the process of EMS 14001 response to environmental protection at Company A. Case study method is defined as "A case study is an empirical inquiry that investigates a contemporary phenomenon in depth and within its real-life context, especially when the boundaries between phenomenon and context is not clearly evident" [18]. In this case Company A, a petrochemical company in Malaysia, located at Kuala Lumpur is used as an example to explain the application of EMS 14001 as instrument for environmental protection. 


\section{Case description: 'Company ' $A$ '}

A case study was conducted in one of the leading petrochemical companies in Malaysia. A pseudonym is used to describe the company, which is referred to as 'Company A'. Established in 1997, Company $\mathrm{A}$ is one of the leading petrochemical company in Malaysia. It is one of Malaysia's national oil company subsidiaries and whollyowned by the Government. Company A and the group-wide entity are ranked amongst the largest companies in the world with a proven track record in integrated oil and gas operations. a total combined production capacity of over 10 million metric tons per annum (mtpa), Company A and the group-wide entity involve primarily in manufacturing, marketing and selling a diversified range of chemical products, including ammonia commercially, as well as supplying carbon monoxide (CO) and oxogas (a mixture of hydrogen and $\mathrm{CO}$ ), olefins, polymers, fertilizers, methanol and other basic chemicals and derivative products.

\section{Why Company A?}

There are several reasons why Company A was chosen as a case single case study to serve the purpose of explaining the process of EMS 14001 as instrument for environmental protection. Firstly, Company $\mathrm{A}$ is chosen due to the uniqueness of the case. It is a leading petrochemical company in Malaysia thus appropriate to be examined.

The uniqueness of the case contributes to the insightful understanding of the issue thus provide rich and thick description of the topic understudy. The adoption of EMS ISO14001 in Company A, give credit to the company being chosen as sample of study.

Secondly, Company A is a 'representative' of a 'typical case'. Company A is one of the big conglomerates of 25 chemical companies in Malaysia. The governance, green practice and EP objective of Company A and other group-wide entities are similar. Therefore, as mentioned by Yin [18], Company A was 'representative' of a 'typical case'. Thus, the everyday circumstances in Company A and group-wide entity could be said to be similar. Additionally, a manufacturing firm is typical of other manufacturing firms within the same industry. A chemical company that produces Ammonia, Carbon dioxide and Oxogas has therefore similar manufacturing activities. Furthermore, how Company A manages its scheduled wastes ethically represents its social responsibility towards EP in Malaysia.

\section{RESULTS AND DISCUSSION \\ Environmental Management System (EMS) ISO14001: Document-based Procedure and Practice}

The EMS is a management system put in place to protect the environment. Although the EMS subscribes to ISO 14001, which is a structured approach to address health, safety and environmental issues, this study solely focuses on the green practice on the environment. Because EMS ISO14001 is based on Company A's real practice, the process could be best described by key informant no 1 and key informant no 3 , as shown below:

Key informant no 1:

"...We can tackle all issues in a systematic approach. Meaning not every day we need to enforce the procedures. At the end, we do hope everybody will play their role, contribute to the system so it can run simultaneously with the company's objective on environmental protection..."

Key informant no 1:

"...So, the issue will be tackled in terms of a 'holistic approach', and more towards governance. Meaning, people do not have a chance to cheat, because all/every elements of the system (ISO 14001) have been audited and monitored. So it's all on cultivating voluntary responsibilities among employees..."

Key informant no 3:

“...By having EMS and certified bodies like SIRIM to monitor our system, we have to comply with the requirements and of the requirement are resources and responsibilities of the top management. By having that (EMS) we have a platform to support the management..."

Key informant no 3

"...EMS is directly related to ISO14001 standard and, yes, when we talk about EMS, it is actually related to understanding of ISO 14001 globally. Because it is a globally accepted system which controls or governs our environmental management system..."

This study focuses on scheduled wastes management as an example to explain the process involved. Company A embraces the EMS framework as the methodology to identify environmental hazards produced in its daily operations. Environmental hazards refer to effluents, emissions, schedule wastes, land pollution etc. This section onwards looks at the whole document of EMS ISO14001. Previous studies has deliberate that EMS 14001 is a certified 
environmental protection measures used among companies in Malaysia. [9]. There are also empirical evidence that cite, companies gained benefits from EMS ISO 14001 [10]. One of the key matter in using EMS ISO14001 is it provides value-based thinking among companies, not to mentioned the sustainability value [11]. On that note, studies have proved that developing a pattern to design a sustainability supply chain based on several requirements, including ISO 14001 [13]; providing an immediate image about the reality of the EMS as experienced by Algerian certified ISO 14001 companies [14]; and the effect of ISO 14001 on environmental regulatory compliance in China [15] are some of the benefits of adopting EMS 14001.

The cycle of activities can be understood as follows: (1) the company first commits to an environmental policy, then uses its policy as a basis to establish a plan, which sets the objectives and the targets to improve its environmental performance; (2) the next step is implementation. After that the company; (3) evaluates its environmental performance to see whether the objectives and targets have been met; if (4) targets were not met, corrective action is taken. The result of this evaluation is then; (5) reviewed by top management to see if the said EMS framework is working. The Management later revisits the environmental policy and sets new targets in a revised plan. The company then implements the revised plan. The cycle repeats and continuous improvement occurs.

Key informant 1 later verified that EMS ISO14001 is a core activity of green practice of Company A:

"...EMS is improving the process from time to time because the nature of the product is risky so that's why we have undergone monitoring, auditing, and a certification process which is tight and comprehensive..."

\section{CONCLUSIONS}

This paper began by explaining the process of how EMS 14001 was used as environmental protection instrument at a Petrochemical Company. Based on in-depth single case study, the model of green practices was established. The model delineates the process of green practices implemented based on the document of EMS ISO14001. An environmental management system (EMS) is a part of excavating management coordination that crafts a framework for the procedures, responsibilities, and processes required to preclude adversarial ecological, commercial, and public impacts and allows for constant improvement. Through its commitment to persistently improve the environmental performance of the business, EMS is the answer if the companies strive for continual improvement in performance towards environmental sustainability. While conducting the study, several ideas emerged that could contribute to future research. The first, the limitation of a single case study could be advanced to use multiple case study. Second, considering the topic is also sensitive to other industries, not exclusive to petrochemical, it is thus suggest that other researchers investigate the process of EMS 14001 at other industries. Third, it is suggest that future research focus on seeking knowledge on how company progressive in respect of its environmental protection initiatives.

\section{Acknowledgment}

The authors would like to acknowledge Universiti Tenaga Nasional (UNITEN) for the fund granted through the Bold 2025 Start-Up Grant Scheme No. RJO10289176/B/1/2017/6

\section{REFERENCES}

[1] Hezri, A. A. and Hassan, M.N. 2006. Towards sustainable development? The evolution of environmental policy in Malaysia. Natural Resources Forum. (30): 37-50.

[2] Tan, S. G., \& Yap, C. K. (2006). Biochemical and molecular indicators in aquatic ecosystems: current status and further applications in Malaysia. Aquatic Ecosystem Health \& Management, 9(2): 227-236.

[3] Al-Shami, Salman \& Salmah, Md \& Hassan, Ahmad \& Ab Hamid, Suhaila \& Siti-Azizah, M. (2011). Influence of agricultural, industrial, and anthropogenic stresses on the distribution and diversity of macroinvertebrates in Juru River Basin, Penang, Malaysia. Ecotoxicology and environmental safety. 74. 1195-202. 10.1016/j.ecoenv.2011.02.022.

[4] Sekaran, R. (2018). Major oil spill heading towards Perak. The STAR online, 27 April retrieved on 8 April 2019

[5] www.malaymail.com. Retrieved on 10 April 2019

[6] https://www.epa.gov/ems. Retrieved on 20 May 2019

[7] Arimura, T. H., Hibiki, A., \& Katayama, H. (2008). Is a voluntary approach an effective environmental policy instrument?: A case for environmental management systems. Journal of Environmental Economics and Management, 55(3), 281-295 
Zeittey Karmilla \& Zaleha / International Journal of Business and Management, 3(2) 2019, Pages: 16-20

[8] WeiqianZhang Weiqiang Wang ShoubingWang. (2014). Environmental performance evaluation of implementing EMS (ISO 14001) in the coating industry: case study of a Shanghai coating firm. Journal of Cleaner Production 64, (1), 205-217

[9] ElTayeb, T.G., Zailani, S. and Jayaraman, K. (2010). The examination on the drivers for green purchasing adoption among EMS 14001 certified companies in Malaysia. Journal of Manufacturing Technology Management. 21(2): $206-225$.

[10] Tan, L. P. (2005). Implementing ISO 14001: is it beneficial for firms in newly industrialized Malaysia?. Journal of Cleaner Production, 13(4): 397-404.

[11] Petros Sebhatu, S., \& Enquist, B. (2007). ISO 14001 as a driving force for sustainable development and value creation. The TQM Magazine, 19(5): 468-482.

[12] Psomas, E. L., Fotopoulos, C. V., \& Kafetzopoulos, D. P. (2011). Motives, difficulties and benefits in implementing the ISO 14001 Environmental Management System. Management of Environmental Quality: An International Journal, 22(4): 502521.
[13] Chiarini, A. (2012). Designing an environmental sustainable supply chain through ISO 14001 standard. Management of Environmental Quality. 24(1): 16 - 33

[14] Hariz, S. and Lylia Bahmed, L. (2013). Assessment of environmental management system performance in the Algerian companies certified ISO 14001. Management of Environmental Quality: An International Journal. 24(2): $228-243$.

[15] McGuire, W. (2014). Analysis The effect of ISO 14001 on environmental regulatory compliance in China. Ecological Economics. (105): 254-264

[16] Creswell, J.W. (2007). Qualitative Research Inquiry and Research Design: Choosing Among Five Approaches. Second Edition. Thousand Oaks, California: Sage

[17] Corbin, J., and Strauss, A. (2008). Basics of Qualitative Research: Techniques and Procedures for Developing Grounded Theory (3rd ed.). Thousand Oaks, CA: Sage Publications

[18] Yin, R. K. 2009. Case study research: Design and methods. 4th ed. Thousand Oaks, CA: Sage 